\title{
How dare you think divergently!
}

The novel thoughts of Kant and the Rationalists and the restrictive politico-
religio-theological framework in the seventeenth and eighteenth centuries

DOI: https://doi.org/10.30664/ar.111088

(C)(Attribution 4.0 International (CC BY 4.0)

F reethinking seems to be desirable because the human being is seen as an independently thinking being. However, as is well known, freethinking should not be taken for granted: ideological indoctrination, manipulation and propaganda, inter alia, are versatile tools for rulers and, in consequence, regularly repeated phenomena. One of the most drastic intellectual turning points in history occurred in the seventeenth and eighteenth centuries, when the incontestable religious world view of European civilization changed along with early modern science and the Age of Enlightenment. Although freethinking and religion do not have to be thought of as opposed, the period in question includes instances of complex and delicate phenomena, which in this article are termed intellectual purism and socio-intellectual control. The discussion includes how five thinkers (Descartes, Spinoza, Leibniz, Wolff, Kant) operated in a restrictive politico-religio-theological framework and how they manifest religious deviance.

René Descartes (1596-1650), Baruch (or Bento or Benedictus) Spinoza (16321677), Gottfried Wilhelm Leibniz (16461716), Christian Wolff (1679-1754) and Immanuel Kant (1724-1804) are distinguished philosophers of the early modern period. All, except Kant in his critical period, that is, the critical Kant, represent the philosophical movement known as rationalism: a rationalist sees human reason as the main element of human understanding, and to it sense experience is subordinate. Kant's critical philosophy is based on an idea of transcendental idealism, which is a ground-breaking theory of the limits of human understanding, and an idea of Kantian ethics, that is, the specific view of human moral autonomy (Kant 2009: 50 and 51), ${ }^{1}$ in which case dedication to traditional religious doctrine may be problematic. $^{2}$

The first three of the philosophers just mentioned have been called 'rationalists par excellence' (Huenemann 2008: 2) and 'canonical rationalists' (Phemister 2006: 215) because each of them propounded a novel philosophical system. Wolff is less known but has permanent merits concerning the explication of Leibniz's philosophy and improving German-language philosophy (Beck 1969: 274 and 275; Hettche and

1 For more on Kant's critical philosophy, see the overview by Michael Rohlf (2020).

2 For more on rationalism, see Huenemann 2008; Nelson 2005. For more on the similarities and differences between these rationalists, see Huenemann 2008; Phemister 2006. For more on the notion of autonomy in Kant, see Beck 1969: 491; Scruton 1982: 60-5. For more on Kant's religious views, see the overview by Lawrence Pasternack and Courtney Fugate (2021). 
Dyck 2019: passages 1 and 2). Kant's critical philosophy is considered to be one of the cornerstones of modern philosophy (Beck 1969: 434; Rohlf 2020: first paragraph; Russell 1945: 704). At this point, it would not be difficult to deduce correctly that they encountered difficulties because of their unconventional views. ${ }^{3}$ Difficulties were heaped upon them by various authorities, including accusations of heterodoxy and atheism, as well as threats of excommunication, banishment and public contempt. What is surprising is that their views were ultimately neither atheistic nor anti-spiritual. Although their motives were mainly theoretical, some were ethical, practical and spiritual. Thus, it can be argued that these five thinkers also sought for intellectually and ethically reasonable practicality and spirituality. Leibniz's philosophy may be the best example of this aim: he thought that with the help of his novel metaphysics the doctrines of Catholicism and Protestantism could be integrated (Antognazza 2009: 7 and 8; Huenemann 2008: 15). At the same time, some of their views were unorthodox, radical and shocking; for example, Spinoza's view could be conceived as unconventional because he identifies God with nature (Spinoza 2002: 247), and, consequently, he was even seen as an atheist (Huenemann 2008: 15; Nadler 2004: 31; Schwartz 2012: 16).

In this article, I look at connections between the restrictive authorities and the philosophers mentioned above in the seventeenth and eighteenth centuries. ${ }^{4}$ To be precise, I examine how the notions of

3 The development of their novel ideas is naturally dependent on the surrounding intellectual culture.

4 For more on the central topics of this period, see Gatti 2015; Hellyer 2008; Israel 2001. religious deviance and a restrictive politico-religio-theological framework are manifested in this context by using methodological terms for analysis. Therefore, this study contributes to the discourse of religious deviance. ${ }^{5}$ Furthermore, I approach the object of the study with the heuristic idea of religion and cultural change, which is based on the postulate that this change has a twofold nature: on the one hand, there are the dramatic breaking points, and, on the other hand, there are slowly evolving transformations. I contextualize the object of study in the second section. In the following five sections I scrutinize each case, including consideration of the background and central issues. Lastly, I present an interpretative analysis with a critical discussion. The reason for selecting these five philosophers is that their various cases illuminate, ${ }^{6}$ particularly well, in my opinion, the dramatic clash between philosophical freethinking and religiously oriented intellectual purism. ${ }^{7}$ The methodological terms are as follows: (1) (intellectual) freethinking means the individual's right to form and propound personal but justifiable views about things, (2) intellectual purism means shared traditional rules and ideas, which limits expression of opinion and individuals' thinking, (3) spiritual authority means a group of individuals, who have societal or religious influence and power to affect public views by different means, such as

5 For more on this discourse and the definition of deviance, see Goode 2015; Rüpke 2016; Sack 2007.

6 There are, of course, many intellectuals, such as Pierre Gassendi, Thomas Hobbes, David Hume, Julien Offray de La Mettrie, John Locke, Richard Simon and Voltaire, whose work relates essentially to this subject matter.

7 For more on this topic, see Gatti 2015: 31-116. 
condemnation and sanctions, (4) sociointellectual control means a shared control of traditional ideas, rules and views, and (5) the restrictive politico-religio-theological framework means a wider restrictive setting of an intellectual activity with respect to a political, religious and theological background; (6) religious deviance is defined in the next section. In addition, by spirituality I mean a general and especially intellectual inclination towards the unseen and transcendent. ${ }^{8}$

\section{The cuius regio, eius religio principle and religious deviance}

Descartes lived in France and the Dutch Republic, Spinoza in the latter, while Leibniz and Wolff lived in the Holy Roman Empire, and Kant in Königsberg. Thus, the geographical and historical context is Western and Central Europe in the seventeenth and eighteenth centuries. The events in this area during this period are miscellaneous, including Louis XIV's reign and the heyday of France and the Thirty Years' War (1618-48). The historians Eric Hobsbawm and Hugh Trevor-Roper have argued that not only the European economy but also in fact European culture in the seventeenth century was mainly in a state which can be called general crisis (Hobsbawm 1954: 33-9; Trevor-Roper 1959: 31; Trevor-Roper 2001: 43-81). Unsurprisingly, religious matters and theological disputes were involved in these problems (Trevor-Roper 2001: 2 and 3), ${ }^{9}$ and one consequence was the Thirty Years' War between Protestants and Catholics with all the consequent atrocities and large-scale devastation. ${ }^{10}$ Therefore, an

8 This should not be confused with the Kantian term 'transcendent' (see Kant 1996: 349).

9 For more on this topic, see Trevor-Roper 2001: $2-42$. inseparable aspect of the context of the subject in question is the problematic politicoreligious situation.

There were two crucial factors, a custom of regional religious control and a longterm intolerant ideology concerning religious deviance, which restricted free intellectual activity and freedom of speech. Concerning the first, a famous Latin proverb, cuius regio, eius religio, that is, 'whose realm, their religion', is a political and religiously oriented legal principle, which was an essential part of the Peace of Augsburg. The central idea is that the principal agent of the political power - whether an individual, group or nation - has a legitimate right to choose a religion or religions for its subjects. Although the purpose of the principle was beneficial, it also can be understood in the negative sense as follows: an individual does not have the right or freedom to dissenting opinions by virtue of the principle decreed by his society and its rules (Allan 2018: section 14.1). Consequently, there is a problematic connection between governance and individual intellectual freedom. At worst, unconditional observance of the principle may lead to religious oppression or violence, and eventually violent religions assuming the notion of religious violence becomes acceptable. ${ }^{11}$

10 To be precise, the war was 'a cluster of military conflicts that often had little in common with one another' (Stollberg-Rilinger and Mintzker 2018: 88).

11 For more on the favourable views, see Clarke 2014; Cliteur 2010. However, William Cavanaugh denies that there is a transhistorical and trans-cultural essence of religion. He argues that separation of religious violence and secular violence is fundamentally incoherent because the myth of religious violence, which is a Western concept, helps to construct and marginalize a religious Other (Cavanaugh 2009: 3, 4 and 7). 
It is to this starting point that the notion of religious deviance, which is related essentially to intellectual purism and sociointellectual control, can be traced. Fritz Sack has put forward the following sociological definition of 'deviance':

Deviance [Abweichung] is any activity perceived to infringe a generally valid norm of a society or of a particular group within that society. Thus deviance is not a phenomenon that is regarded merely as atypical or unusual ... In order for behaviour to be regarded as deviant, it must be judged to offend against binding, socially defined standards. And, as many such standards, but not others, are codified in statutes, the phenomenon of deviance includes criminal behaviour [kriminelles Verhalten] ... but also behaviour that, while not regarded as illegal, is generally seen as unethical, immoral, eccentric, indecent [unethisch, unmoralisch, eigenartig, unanständig], or simply 'unhealthy' [krank]. (Rüpke 2016: 3, translated by D. Richardson; Sack 2007: 184)

'Deviance' can be divided now into two parts: proper illegal activity and otherwise exceptionable activity. Furthermore, Sack's definition seems to be appropriate to the religious context. In particular, it seems that other relevant notions, such as blasphemy, heresy or heterodoxy, religious taboo, paganism and unorthodox religiosity, which have been considered either illegal or exceptionable activity at different times, can be derived from that elementary idea. For example, when some Jews accused Jesus of blasphemy - for saying that God and he are one (John 10: $30^{-} 3$ ) - his act, from their perspective, was not only immoral and indecent, that is, an exceptionable activity,

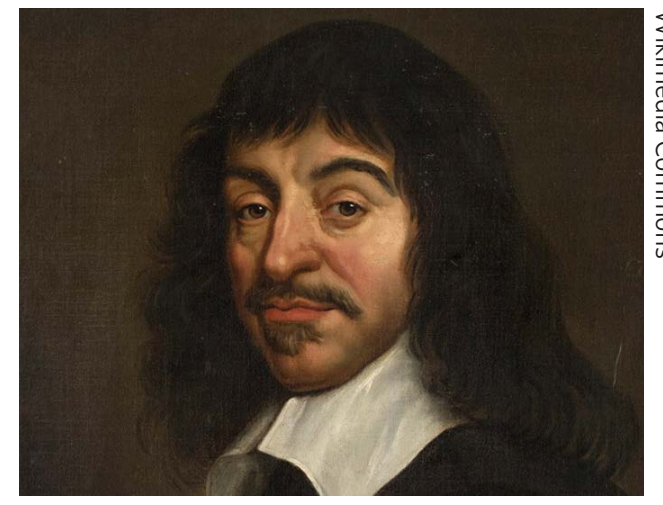

René Descartes (1596-1650).

but also a punishable act on the grounds that it was a proper illegal activity because God had commanded that 'anyone who blasphemes the name of Yahweh shall be put to death' (Leviticus 24:16) (Allan 2018: section 14.3.1). Therefore, the sociological definition above is seen as the general definition of religious deviance here.

\section{Descartes and the Dutch Republic's obstructive forces}

Descartes propounded, inter alia, arguments for the existence of God, the modern formulation of the mind-body problem, a theory of mind-body dualism and a new method of doubt in his philosophy, which is termed Cartesianism. ${ }^{12}$ What is more, he was a devout Catholic who tried to avoid political and doctrinal disagreements with the church (Gaukroger 1995: 4; Huenemann 2008: 14 and 15). Descartes thought that God exists indubitably and is good and reliable, that atheists cannot have immutable and certain knowledge, and that Christian governments, that is, governments with the true religion ('la vraye Religion', AT VI, 2: $12^{13}$ ) with the laws given by God, are better

12 See Hatfield 2018.

$13 \mathrm{AT}=$ CEuvres de Descartes (13 vols, 18971913), cited by volume, part and page number. 
ordered than others (Descartes 1985b: 35, $46,47,117,289)$. Therefore, we can be quite certain of Descartes's Christian faith and Catholic identity.

Nevertheless, Descartes came into conflict with the Dutch Republic's religious authorities. The context of the incident as well as the dispute itself are complex (Verbeek 2015a: 83). The context was that the Remonstrant controversy had arisen, including several doctrinal questions of Arminianism, in which the Remonstrats had allied themselves politically with Cartesianism, even though there were significant doctrinal differences between Cartesianism and Arminianism. Later, the Dutch Republic was divided into two sides concerning the controversy over Remonstrantism and the prevailing Calvinist orthodoxy (Gaukroger 1995: 357-9). ${ }^{14}$ Regarding the dispute itself, Gisbertus Voetius (1589-1676), who was a Calvinist and professor of theology at Utrecht and involved with the ultra-orthodox wing of the Dutch Reformed Church, that is, the Contra-Remonstrants (Verbeek 2015b: 754), and Martinus Schook (161469), a young professor of logic and physics at Groningen and most probably a Calvinist too, accused Descartes of atheism and scepticism. ${ }^{15}$ Voetius's accusation is based on his conception of 'atheism,' ${ }^{16}$ which is identified with irreligion and can be open or hidden. Voetius thought that by means of this conception every dissenter, such as Descartes and the previously executed

14 For more on these topics, see Hsia and Van Nierop 2002.

15 According to theological scepticism, the existence and nature of God are beyond human understanding.

16 See Verbeek 1991: 212, 213; Voetius 1648: $117^{-25}$ ('gradus \& species Atheorum' (p. 117 ): grades and qualities of atheists, translated by V. H.).
Giulio Cesare Vanini (1585-1619), ${ }^{17}$ could be classified and condemn ${ }^{\text {ed }}$. To be precise, Voetius accused Descartes of opposing the traditional Aristotelian and scholastic philosophy, of using new but harmful philosophical terms, which spoil the understanding of the young, and of conflicting views with orthodox Calvinistic theology (Descartes 1985b: 393 and 394). Voetius thought that only the word of God can be the source of faith (Verbeek 1991: 221). Schook's accusation, which is included in his book Admiranda Methodus Novae Philosophiae Renati Des Cartes (1643), was again that Descartes's proofs for the existence of God are uncertain and weak: ${ }^{18}$ he saw, unlike Descartes, that no finite human being can have the idea of an infinite God (Verbeek 1991: 212-14). In consequence, the Utrecht town council officially accused Descartes of slandering a clergyman. Descartes's counterstroke was as follows. First, he a wrote a long letter to Voetius, ${ }^{19}$ in which he treats mainly theological issues by explaining his views, and a shorter letter to the magistrates of Utrecht, ${ }^{20}$ in which he defends himself officially. Second, Descartes persuaded his friends of political eminence and other political authorities of France to intervene in the situation. As a result, the magistrates refused to find Descartes guilty. Schook was even forced to admit under oath that Voetius was responsible for the main claims against Descartes (Gaukroger 1995: 360, 361).

What is Descartes's case about? To start with, there had been long-term political

17 Vanini, a philosopher and priest, was sentenced to the death penalty for atheism in 1619.

18 See Schoock 1643: 172-89.

19 See AT VIII, 2: 1-194.

20 See AT VIII, 2: $279^{-} 317$, in French: AT VIII, 2: 201-73. 
and religious unrest between different groups in the Dutch Republic. Although the problems were often mainly political, doctrinal matters, which were partly related to political and societal power structures, could easily become controversial issues. Calvinism represents intellectual purism in this case. Voetius and Schook represent a secondary spiritual authority because they were the prime movers in the campaign against the Catholic Descartes and his heretical views, and because they were traditionalist and strict followers of the Scripture, who relied on the outline of the Synod of Dort (Verbeek 1991: 221, 222). The magistrates of Utrecht represent the primary spiritual authority because they possessed jurisdiction. Voetius, Schook, the magistrates of Utrecht and their allies together represent socio-intellectual control. Although there is a certain rationale for Voetius's and Schook's accusations, Cartesianism is not, according to Theo Verbeek (pp. 221-3), ultimately a proper threat to religion. Furthermore, although Descartes was a Catholic, he was nevertheless dedicated to Christianity and desired to co-operate regarding theological issues and doubts. ${ }^{21}$ Therefore, in my opinion Descartes is not particularly religiously deviant. However, it seems that his novel and partly radical philosophical views (Verbeek 2015b: 83) regarding, inter alia, his dualism and method of doubt, along with his sympathies for the Remonstrants led to objections from Voetius and Schook and caused them to perceive this as a case of religious deviance.

21 See e.g. Descartes 1985a: 291 (note especially: 'I submit all my views to the authority of the Church', italics removed).

\section{Spinoza's 'monstrous heresies'}

Spinoza, who abandoned Judaism formally but not completely from an intellectual position (Nadler 2014: 3 and 4), is considered to be one of the most radical philosophers (Hampshire 1988: 34 and 35; Israel 2001: 159; Nadler 1999: xi). His ambiguous philosophy (Hampshire 1988: 6 and 7; Nadler 2014: 2), Spinozism, is unorthodox in many ways, and especially by Judaic tradition and standards. ${ }^{22}$ Consider, for example, the following passage in the Ethics: ${ }^{23}$
I have now explained the nature and properties of God: that he necessar- ily exists, that he is one alone, that he is and acts solely from the neces- sity of his own nature, that he is the free cause of all things and how so, that all things are in God and are so dependent on him that they can nei- ther be nor be conceived without him, and lastly, that all things have been predetermined by God, not from his free will or absolute pleasure but from the absolute nature of God, his infinite power. (Spinoza 2002: 238)

Here we can see an unusual description of God and the world. First, all things are in God, which seems to imply pantheism. Second, things cannot be conceived without God, which implies monism, that is, a postulate of one substance. Then, human beings are finite modes (or parts) in the infinite God. Third, God does not have free will, and He acts by necessity, ${ }^{24}$ which

22 See e.g. Nadler 2020: sections 1 and 3.1.

23 Spinoza finished the Ethics in 1675 but left it unpublished because the situation was extremely tense. The book was published posthumously in 1677; Steenbakkers 2009: 26 and 35.

24 Cf. propositions $14,15,24,32$ and 33 of the first book. 
seems to have the following corollary: free will is impossible by virtue of the absolute determinism, that is, necessitarianism. Furthermore, Spinoza describes the function of holy scriptures in the controversial Theological-Political Treatise (published anonymously in 1670) as follows:

But it will be said that, although God's law is inscribed in our hearts, Scripture is nevertheless the Word of God, and it is no more permissible to say of Scripture that it is mutilated and contaminated than to say this of God's Word. In reply, I have to say that such objectors are carrying their piety too far, and are turning religion into superstition; indeed, instead of God's Word they are beginning to worship likenesses and images, that is, paper and ink. ... I also declare with certainty that I have said nothing that is impious. (Spinoza 2002: 504)

This passage gives hints about Spinoza's politico-religious view. He thought that the Scriptures can only be a kind of moral message, whereas free philosophy is a proper source of truth, and that the usage and interpretation of the holy scriptures easily leads to problems, such as to sectarian disputes and even religious wars. Thus, consenting to freedom of philosophizing is the only possible choice for him (Nadler 2020: section 3.1). Unsurprisingly, several sectors were opposed to Spinoza's philosophy (Israel 2001: 161; Nadler 2020: section 1; Schwartz 2012: 15-17). He was even regarded as 'the most pernicious and dangerous thinker of the era' (Israel 2001: 161). Nonetheless, Spinoza is not explicitly an atheist, and he has ethical spirituality; he thinks that intellectual love for God, that is, the active and generative aspect of nature (Nadler 2004: 32), the impersonal Natura

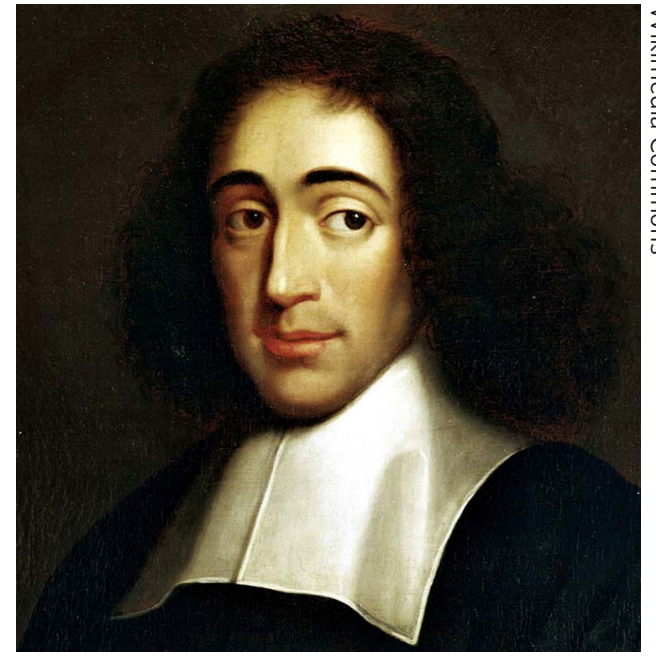

Baruch Spinoza (1632-1677). Unknown author, c.1665. Herzog August Bibliothek, Wolfenbüttel, Germany.

naturans, enables a good and virtuous life (Hampshire 1988: 128-30; Spinoza 2002: 371-82).

Spinoza grew up in Amsterdam's Portuguese-Jewish Sephardic community and received a Judaic education. When he was only 23 , Spinoza and the community came into an insoluble conflict. Before that, he had diligently studied Latin and new philosophies (Nadler 1999: 115). According to the public proclamation, Spinoza had 'evil opinions and acts' (Nadler 2004: 2). Reliable information had also been received 'about the abominable heresies which he practiced and taught and about his monstrous deeds' (p. 2). As a result, Spinoza was banished from Amsterdam's Sephardic community by the agreement of the congregation. To be precise, he was excommunicated (cherem $^{25}$ ), expelled, cursed and damned by the parnassim (chief administrative officers) of the mahamad (council of elders) on the grounds of the rabbinic assessment (Albert 2014: 173-5). Furthermore,

25 For more on cherem, see Nadler 2004: 1-29. 
according to the latter part of the proclamation, 'no one should communicate with [him], neither in writing, nor accord him any favour nor stay with him under the same roof nor [come] within four cubits in his vicinity; nor shall he read any treatise composed or written by him' (Nadler 2004: 2; the latter square-bracketed word is Nadler's). The pronounced punishment has been seen as grave and uncommon (Albert 2014: 174; Nadler 2004: 3 ). The rabbis probably included Saul Levi Morteira (c. 15961660) and Isaac Aboab da Fonseca (160593) (Nadler 2004: 13). Nevertheless, we do not know what Spinoza's wrongdoings in fact were. Although there is a small possibility that they were linked to Spinoza's financial issues regarding payments of the congregation (Nadler 1999: 118-20), the excommunication was most probably given for doctrinal reasons (Nadler 2020: section 1). According to Jean Maximilien Lucas's account, Spinoza was 'not convicted of blasphemy but only of a lack of respect for Moses and for the law' (Nadler 2004: 12). Whatever the truth is, he had to leave his family, friends and community. He has later been seen, however, as the first modern secular Jew (Schwartz 2012: 2). Furthermore, Spinoza's work has even been regarded as the principal inspiration for Dutch republicanism (Gatti 2015: 7).

How does Spinoza's case reflect religious divergence? To begin with, Amsterdam's Sephardic community was a minority religious group and a subgroup of Judaism. It was most likely in straitened circumstances between the Catholic and Protestant mainstream cultures. It also seems that within the community there were power-sharing struggles concerning the mahamad's, rabbinical and civil authorities (Albert 2014: 171-3). The parnassim of the mahamad and the rabbis, including probably Morteira and Fonseca, represented spiritual authority with their Judaic traditions and observance of the Hebrew Bible intellectual purism. Amsterdam's Sephardic community represents socio-intellectual control - the judgement seems to be unanimous, without any known and distinct dissenting positions. Spinoza was likely to have been seen as, at the very least, a problematic member of his community because he was not only a bright critical individual but a radical freethinker, who denied more or less openly the Mosaic authorship of the Pentateuch (Peters 2007: 83 ) and endorsed intellectual freedom and new philosophies, such as Cartesianism. Consequently, Spinoza was conceived as a religious deviant most probably because he espoused new and dubious views, which materialized later in the Ethics. According to Jonathan Israel, Spinoza's case manifests well the idea of the radical enlightenment because he was 'a chief challenger of the fundamentals of revealed religion, received ideas, tradition, morality, and ... divinely constituted political authority' (Israel 2001: 159). In my opinion, it is easy to see, in the end, why Spinoza was regarded as divergent: he opposed common Judaic traditions radically, explicitly and publicly, which was seen as immoral and indefensible.

\section{Leibniz and his exceptional ecumenical project}

Leibniz is seen as 'the last universal genius' (Look 2020: first passage). He is known for his extensive correspondence as well as for his high-level social contacts with prominent nobles, such as Johann Christian von Boyneburg, Johann Friedrich of Brunswick and Sophia of Hanover. According to Bertrand Russell's impression, which has been contested later (Antognazza 2009: 4,5 ), there are two philosophical systems which may be regarded as representing Leibniz: one, which is 'optimistic, orthodox, fantastic, and shallow', and by which 


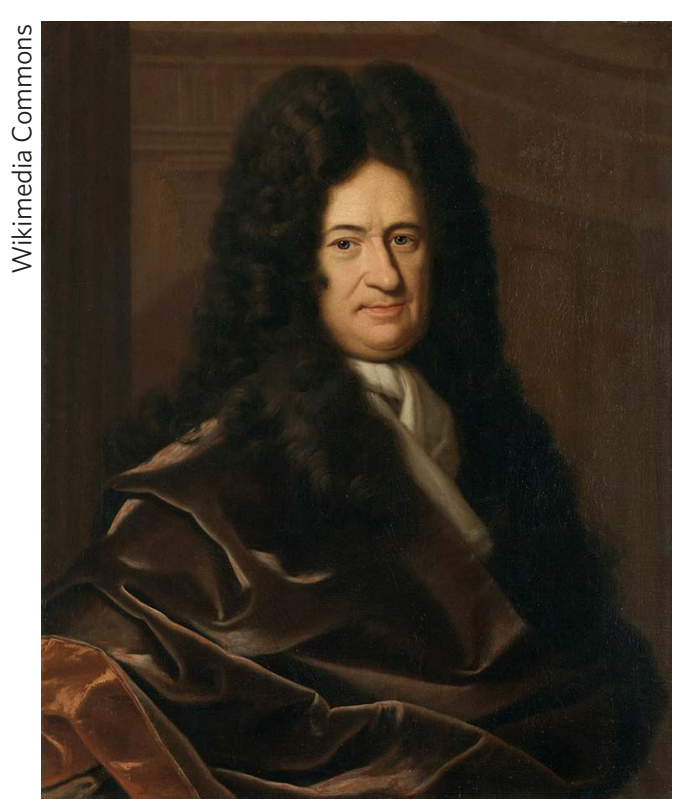

Gottfried Wilhelm Leibniz (1646-1716). Christoph Bernhard Francke, oil on canvas, 1695. Herzog Anton Ulrich Museum.

he tried to gain the approbation of 'princes and princesses', and the other, which is 'profound, coherent, largely Spinozistic, and amazingly logical', and which was put together from his manuscripts (Russell 1945: 581). Whatever the truth is, he spent time in the houses of the nobles whilst developing his novel views.

There are explicit passages where Leibniz approves of Christianity, ${ }^{26}$ and he is seen as devout Christian, Lutheran and Evangelical (Antognazza 2009: 29 and 546; Huenemann 2008: 14 and 15). However, it is unclear what the exact nature of Leibniz's Christian faith was, as he seemed to believe in something which can be called the universal church (Antognazza 2009: 29; Huenemann 2008: 145). This aspiration appeared early: when Leibniz was only 22 years old, he had a broad-minded

26 See Leibniz 1989: 68, 298, 299; Leibniz 1998: 49-51. plan, the plan of catholic demonstrations, by which theology, certain parts of metaphysics, logic, mathematics, physics and politics could be unified (Antognazza 2007: 3; Look 2020: section 1). One issue, which explains Leibniz's ecumenical motives, is the Thirty Years' War (Huenemann 2008: 107; Look 2020: section 1), which caused large-scale devastation in Leibniz's hometown of Leipzig. Eventually, Leibniz became 'a consummate synthesizer' (Huenemann 2008: 109) with his irenic aim. Although he composed a myriad of writings, he published only one philosophical book, the Theodicy (1710), which includes many of his central philosophical ideas, and which is seen as a forerunner of his grand plan (Antognazza 2009: xxvi). In consequence, Leibniz's late-period philosophy can be seen as a more detailed framework of this plan; it includes, for example, the following ideas: ontological pluralism - unlike Descartes's dualism (mind and matter) and Spinoza's monism (God or Nature) - is true; substance, that is, a monad, is immaterial, simple, shapeless, unique, capable of action, naturally indestructible, and with perception; God is omniscient, omnipotent, absolute benevolent and the origin of the monads; the world is pre-established by God; the world is the best possible world by virtue of God's properties (Leibniz 1989: 206-25). Ultimately, Leibniz did not manage to find suitable allies, despite his high-grade contacts, and was thus not able to realize this mission. His last years were bitter; he was forced to stay at the House of Hanover regardless of his own wishes. The quarrel previously started with Newton on the famous invention of the calculus continued in Newton's favour, and Leibniz failed to convince the British theologian and Newtonian Samuel Clarke (16751729) concerning his views on space and time, and finally support from the court of 
Hanover began to wane (Antognazza 2009: 521; Look 2020: section 1). Leibniz was not even given a decent funeral, despite being internationally well known and respected (Ariew and Garber 1989: x), and representatives from the most significant scientific, political or religious sectors simply did not bother to attend (Antognazza 2009: 545). Charlie Huenemann states, as a conclusion, that

[Leibniz's] life is the sad story of a brilliant man ready to turn all of his intellectual energies towards making the world a better place, and who experienced mainly rejection and neglect. By the time of his death in 1716 he was a nearly forgotten man, and his grave went unmarked for 50 years. (Huenemann 2008: 108)

Leibniz's case is different from the two previous cases because his views did not result in official investigations, albeit there were repeated rumours about his conversion to Calvinism or Catholicism (Antognazza 2009: 28, 503). One of the main reasons that there were no official investigations was probably because Leibniz received protection from his noble contacts, but presumably not without conditions; he had to be careful concerning his religious or theological statements because it was quite possible that someone, such as one of his powerful protectors, ${ }^{27}$ could consider his views as heterodoxy and thus classify him as a religious deviant. Therefore, the courts and houses with changeable but traditional royal and noble predilections $^{28}$ represent intellectual purism, spiritual authority, and above all the source

27 See e.g. Antognazza 2009: 503.

28 For more on this topic, see Antognazza 2009. of socio-intellectual control. It is plausible that Leibniz had to perform balancing acts constantly: he had to suitably flatter his patrons so that he could secure his position whilst subtly indoctrinating them with his righteous thoughts. In consequence, the nobles did not condemn him officially nor prevent his intellectual pursuits, albeit they did not assist him in his mission either. In the end, Leibniz was not alleged to be religious deviant, but, in my opinion, there was a possibility that he might have been accused because many of his philosophical views, such as the idea of a pre-established harmony, ${ }^{29}$ are extraordinary and thus potentially heretical.

\section{Wolff versus the Pietists of Halle and the Soldatenkönig}

Wolff is regarded as the most important German philosopher between Leibniz and Kant (Hettche and Dyck 2019: paragraphs 1 and 2). Although Wolff agreed for the most part with Leibniz's philosophy, he was more problem-oriented and demanded practical utility from rationalistic-based philosophy by means of empirical methods (Fugate and Hymers 2014: 15-20; Hettche and Dyck 2019: section 4). Wolff received a Lutheran education in Breslau's Catholic milieu, which was not without theological controversies (Beck 1969: 256). He corresponded with Leibniz from 1704 to 1716, who also assisted him in his obtaining a professorship of mathematics at the University of Halle (Hettche and Dyck 2019: section 1). Although Wolff advocated the separation of philosophy and religion and thought that morality does not depend on revelation or divine commands, he argues for the existence of God (Beck 1969:

29 See e.g. Leibniz 1989: 207, 208, and 212; Leibniz 1998: 180 and 181). 


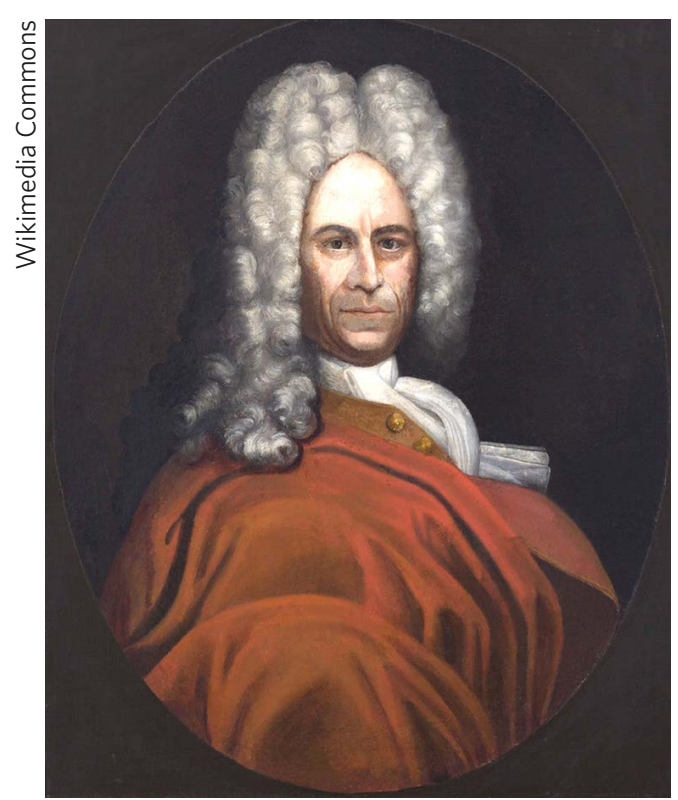

Christian Wolff (1679-1754). Unknown author, c.1735. Museum für Kunst und Kulturgeschichte der Philipps-Universität Marburg.

272-4; Hettche and Dyck 2019: sections 5.4 and 6; Wolff 1737: 15-17; Wolff 1751: 583, 584). Furthermore, Wolff explicitly argues against atheism (Beck 1969: 273; Wolff 1737: 491 and 491). Therefore, it seems that he was a Christian and possibly Lutheran.

Wolff's famous clash with the Pietists of Halle is exceptional but has been partly misunderstood. ${ }^{30}$ To begin with, Wolff's popularity as a lecturer and his influence at Halle could be seen to be constantly increasing. Furthermore, he criticized indirectly Pietistic doctrine and orthodox scholasticism in his philosophy (Beck 1969: 273). This caused ill-feelings among the Pietists of Halle (or at least some of them), including August Hermann Francke (16631723), a clergyman and theologian, Johann Joachim Lange (1670-1744), a professor of

30 For more on this complex topic, see the following recent studies: Grote 2017: 18-66; Grote 2018; Rydberg 2021. theology (Beck 1969: 258 and 259; Hettche and Dyck 2019: section 1), Johann Liborius Zimmermann (1702-34), a preacher, spiritual counsellor and theologian, and Nicolaus Hieronymus Gundling (16711729), a jurist and philosopher (Grote 2017: 65). The Pietists soon launched a campaign against Wolff. First, it was known that he had supported Confucian moral philosophy in his lectures, ${ }^{31}$ which was considered as unacceptable. Furthermore, Wolff's philosophy, according to Lange, seemed to be similar to Spinozism. Finally, when Wolff refused to submit lecture notes to the faculty of theology for the subsequent examination, an official investigation was started by the university senate. Although Wolff was supported by officials within the royal court, the Pietists succeeded in persuading the 'Soldier King' himself, that is, Frederick Wilhelm I (1688-1740), who was a moderate Calvinist, to give them support. The final accusation was that the Leibnizian pre-established harmony, which was endorsed by Wolff, threatens military discipline because the acts of deserters would be pre-established beforehand and so not subject to sanction; the Halle Pietists required 'penitential remorse' (Britannica Academic 2021: s.v. 'Pietism'). In consequence, Wolff was banished from Halle and Prussia by the king's edict on pain of hanging. Wolff gained admission to the University of Marburg but ultimately returned to Halle in 1740 by the authority of Friedrich II (1712-1786) (Hettche and Dyck 2019: section 1; Israel 2001: 544, 545). According to Jonathan Israel's interpretation, there were

31 For more on Wolff's defence of 'natural obligation', that is, 'a reason to want or to not want something' (Grote 2017: 24), which was at the centre of the controversy, see Grote 2017: 23-28. 
two main problems in the background: the mainstream Enlightenment was divided, ${ }^{32}$ and radical deism, advocated by Wolff, and Spinozism became so powerful that traditional counterforces were not able to overthrow them; revived counterforces were manifested, inter alia, as Pietist fundamentalism (Israel 2001: 541 and 544). However, this case is not so straightforward. First, several recent revisionist studies have shown that the Pietism of Halle was not particularly irrational or anti-philosophical, nor an intolerant movement. This is contrary to the long-term myth, which is, in fact, a product of Wolffian propaganda (Rydberg 2021: 190). Second, according to Simon Grote, Lange's 'fanaticism' is also a myth, which similarly originated from the Wolffian tradition - to be precise, Lange especially wanted to distance himself from what was conceived by him and some of his contemporaries as 'fanatical' (Grote 2018: 114, 138).33 Therefore, on the one hand, Wolff's banishment is a historical fact, but on the other hand, the confrontation between Wolff and the Pietists of Halle is a complex and delicate whole, which is biased by Wolffian tradition, especially because in the end Wolff so to speak won the intellectual struggle.

How are Wolff's famous case and religious deviance related? First, there was political and religious restlessness in the aftermath of the Thirty Years' War, as already mentioned. The political and

32 For more on the complex connection between religion and Enlightenment, see for example the review essay by Simon Grote (2014).

33 This distancing was related to an alleged accusation of an intellectual kinship between Lange and French Reformed theologian Pierre Poiret (1646-1719) (Grote 2018: 111). intellectual atmosphere was particularly tense in Halle (Israel 2001: 544). Therefore, it is not surprising that intellectual controversies over philosophical and especially theological issues occurred. Pietistic doctrine represents intellectual purism in this case, albeit Pietism had beneficial and scientific merits (Rydberg 2021: 190). The Pietists of Halle, including especially Francke, Lange, Zimmermann and Gundling, who were a primus motor against Wolff, represent the secondary spiritual authority, while Frederick Wilhelm I and the university senate represent the primary spiritual authority because they had jurisdiction, and together they represent sociointellectual control. From the Pietists' perspective - if this dispute was related de facto to doctrinal matters and not personal issues, such as the competition over academic positions, which is possible ${ }^{34}$ - Wolff was above all an intellectual threat. He was also probably seen as religiously deviant, because in the sense of proper illegal activity he opposed Pietistic doctrine in his philosophy, endorsed dubious Leibnizianism and obscure Chinese doctrines, and might even be indirectly a proponent of heretical Spinozism. Nevertheless, it is surprising that Wolff's punishment was similar to Spinoza's, given that Spinoza had openly denied the whole system of his religious community.

\section{Kant versus the Prussian Censorship Commission}

Kant, who had a Lutheran background, was a rationalist at first but later developed his critical philosophy. This change was due to rationalism, empiricism and the ideals of the Enlightenment encountering problems, which were related, inter alia, to the prob-

34 See Rydberg 2021: 190. 
lematic corollaries of mechanistic physics (such as hard determinism, in which free will might not be possible), uncritical metaphysics and epistemology, and the possibility of agnosticism and scepticism. Kant propounded several revolutionary philosophical ideas in his critical philosophy, such as the following: the categories of the understanding are definitive prerequisites for human understanding (Kant 1996: 129-35); the noumenal self, that is, 'I' as a thinking and experiencing being, is a conscious subject, which is not a part of mechanistic nature, and which is thus a free thing (Kant 1996: 318, 319, 540, and 541; Rohlf 2020: section 5.2; Scruton 1982: 44-6 and 60-2); human beings have an inner categorical imperative, which is a maxim and the supreme moral principle, and which applies universally and shows the right ends of action (Kant 2009: 25, 28, and 216; Scruton 1982: 69-71). Furthermore, Kant, according to Roger Scruton, demythologized religion: the kingdom of God is in fact the kingdom of the end of traditional beings, and traditional claims of theology are, in fact, postulates of practical reason (Scruton 1982: 78 and 79). Kant also claims that 'the mere form of a disjunctive syllogism ${ }^{35}$ must necessarily entail the highest concept of reason, viz., that of a being of all beings' (Kant 1996: 377, italics removed), which seems to imply that God is fundamentally a kind of intellectual corollary of human reasoning although he may be real as a transcendental being (Scruton 1982: 78) which is beyond human knowledge (Wood 2020: 4). Moreover, Kant criticizes the traditional arguments for God's existence, and, for that reason, he has been seen as hostile to religion. However, first, although Kant seems

35 The syllogism in question is formally: ' $p$ or $q$ '; 'not q'; 'ergo: $p$ '.

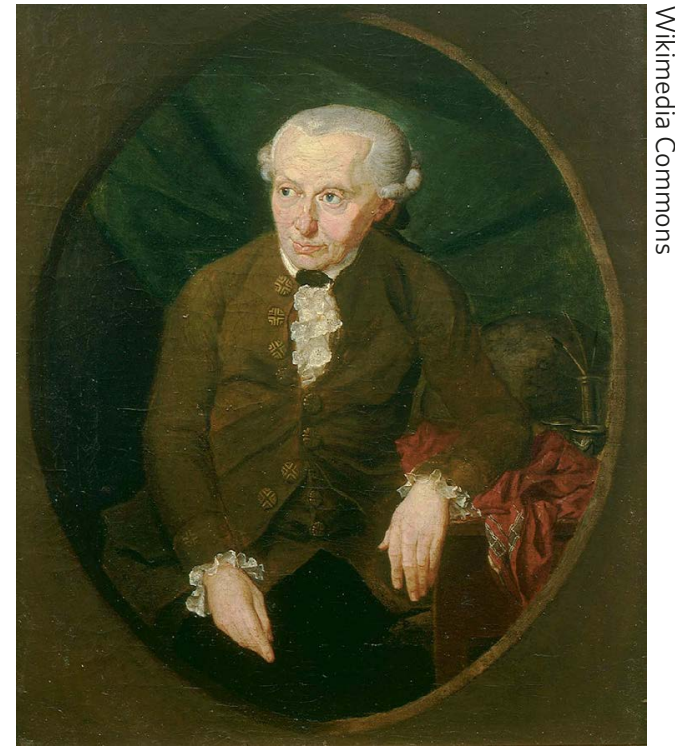

Immanuel Kant (1724-1804). Gottlieb Doebler, 1791. Ostpreußisches Landesmuseum mit Deutschbaltischer Abteilung, Lüneburg.

to challenge religious belief altogether by his critical method, his views are so complex and delicate that research on Kant has continued to this day, ${ }^{36}$ and second, it is important to see that Kant propounds that religion is above all practical, in which case it is an object of pure practical reason. Thus, he does not deny the importance and usefulness of religion at all (Pasternack and Fugate 2021: sections 3, 3.1, 3.3, and 3.6). Ultimately, Kant's critical philosophy is a distinct entity compared to that of the rationalists dealt with above; he advocated a pure rationalism, which is against theological naturalism and supernaturalism ${ }^{37}$ (Wood 2020: 18 and 19): a pure rationalist 'allows for the possibility of divine revela-

36 See e.g. Wood 2020.

37 According to the first, a naturalist 'accepts a pure rational religion and denies that there is any revealed religion', and according to the second, 'revealed religion is universally necessary for any genuine religion' (Wood 2020: 18). 
tion but claims it is not necessarily required for religion' (p. 18).

Unsurprisingly, Kant encountered difficulties because of his new type of views. Along with the new religious policies of Frederick William II (1744-97), the king's manipulative assistant Johann Christoph Wöllner (1732-1800), 38 who was a notorious Prussian pastor and politician, and the Prussian Censorship Commission started to limit religious toleration by censoring publications and controlling lecturing in 1788 by means of the infamous Wöllner edict. Furthermore, Wöllner informed the king about Kant's heterodox writings on Christianity, and the king sent a royal edict - in fact, it was written by Wöllner himself (Wood 2020: 22) - to Kant in October 1794. The letter insisted that Kant must not engage in public discussion of religion nor publish anything on religion because he had misused philosophy by distorting and disparaging the basic teachings of the Holy Scriptures. To be precise, Kant had managed to cunningly avoid censorship by publishing his controversial Religion within the Boundaries of Mere Reason in 1793 so that it was assessed as a work of philosophy, not as a theological work. It is noteworthy that this book is one of the earliest works on systematic demystification of theology. As a result, Kant had to reluctantly bow to the king's insistence (Beck 1969: 434 and 435; Pasternack and Fugate 2021: sections 3.6 and 3.7.1; Scruton 1982: 8, 9, and 78; Wood 2020: 22). Nevertheless, when Frederick William II died in 1797, Kant was free to write on religious matters again. As a consequence, he wrote The Strife of the Faculties in 1798 , which is the first book about the right to free philosophical interpretation

38 On this characterization, see Wood 2020: 11. of Scripture without liability to theological control and censure (Beck 1969: 435).

What is Kant's case about? The atmosphere became more restrictive in Prussia during the reign of Frederick William II, as the king wanted to restore traditional Protestantism because there were growing tensions between Calvinists, Lutherans and Catholics, ${ }^{39}$ and, according to the Wöllner edict, 'the ministers were to be held strictly to orthodox doctrines' (Beck 1969: 435). Thus, the king with his controlling system, including Wöllner, represent spiritual authority as well as socio-intellectual control with jurisdiction and regulation, and their aspiration for 'orthodox Protestantism' (p. 435) represents intellectual purism. ${ }^{40} \mathrm{In}$ his opposition to the idea of religious tolerance, Frederick William II was keen to maintain control, discipline, orthodoxy and traditions. Kant was probably seen as religiously deviant because his views were too complex and ambiguous and were being represented, at this point, as an exceptionable and reprehensible activity. However, they were not as yet regarded as illegal activity as such, which would demand an official investigation, as in Descartes's case, or an investigation and a punishment, as in Spinoza's and Wolff's cases.

\section{Interpretation}

Five cases have been examined: the Catholic Descartes against the Calvinistic Voetius and Schook; the radical Spinoza, a freethinker par excellence, against Amsterdam's Sephardic community; the Evangelical Leibniz and his one-man struggle for the unification of the churches; the Lutheran

39 Cf. e.g. Beck 1969: 434 and 435; Wood 2020: 11.

40 'In Protestant churches the authority of the old tenets of faith should be enforced' (Beck 1969: 435). 
Wolff against the 'Soldier King' and the Pietists of Halle, including Francke, Lange, Zimmermann and Gundling; and finally the critical Kant against the aspiration for 'orthodox Protestantism' by Frederick William II and his regulating system, including the notorious Wöllner and his edict. My first observation is that an indisputable confrontation between freethinking and religious orthodoxy can be found in the Descartes's, Spinoza's, Wolff's and Kant's cases - Leibniz was the only one who did not officially experience problems with the authorities; he was, however, considerably neglected by the religious and political sectors and he was slandered by rumours about the nature of his religious beliefs. On the one hand, these confrontations are in my opinion surprising because these philosophers were not explicitly atheistic nor anti-spiritual: Descartes, Leibniz and Wolff were evidently devout believers, Kant's practical stance is critical but nonetheless favourable and permissive, and Spinoza is the only one who opposed traditional theism but was, nonetheless, most probably a pantheist. On the other hand, they propounded several novel unorthodox and radical ideas, through which they represent, at least partially, an intellectual counter-culture. Therefore, it is unsurprising that they experienced difficulties. My second observation is that the conceptions of religious deviance changed and were context-dependent. For example, Voetius's concept of atheism seems to be very extensive, while the accusation against Descartes, which was partly political, was withdrawn after inspection, Spinoza received his punishment indistinctly for an undetermined false intellectual activity, Wolff's accusation seems to be more or less artificial, and the limitation of Kant's intellectual activity was based partly on political reasons and in particular on Wöllner's religious policies. Furthermore, the communities in question applied a variety of cuius regio, eius religio principles: the communities of Halle and Amsterdam applied it strictly whereas Utrecht's and Königsberg's did so more conditionally. In the most serious cases, religiously deviant individuals might have received the death sentence, as Vanini did earlier. Therefore, it was not clear what constituted a decent amount of 'the core of public religion' (Rüpke 2016: 113), which must not be infringed by intellectuals. My third observation is that the five cases are consistent with the idea of religion and cultural change taking place, since there was both a changing general crisis of the early modern period with religious wars, and intellectual, theological and religious disputes, and a long-term intellectual change from the Middle Ages to the modern age.

Finally, the framework of the intellectual activity in this context was politically, religiously and theologically intertwined and restrictive. Thus, in my opinion this framework can be called a restrictive politico-religio-theological framework, which includes such characteristics as intellectual purism and socio-intellectual control. Furthermore, this framework was essentially a complex and volatile whole, which offers an important perspective on religious deviance. However, there are two preliminary critical remarks regarding the proposed interpretation. First, one issue is the connection between personal issues and doctrinal and intellectual matters: it is not completely clear how much the arguments were ultimately related to personal issues, especially in the cases of Spinoza and Wolff. Second, Wolff's case raises an important issue since it shows that a philosophical tradition (or a narrative) can be propagandist and biased in itself, and contrary to facts which, in a certain sense, seems to be anti-philosophical. 


\section{Concluding remarks}

Intellectually creative individuals met with various challenges in the seventeenth and eighteenth centuries, as has been illustrated. When novel ideas - especially when related to theology - were propounded, no one could say with certainty what would happen and what kind of reception an idea would receive. The discussion presents how these five cases illuminate the problems of intellectual activity of that time. The quality of the reception depended, in addition to proper doctrinal matters, on the social connections of the individual, the prevailing political and religious circumstances and the formulation or mode of the presentation of the arguments. In consequence, Descartes, Spinoza, Leibniz, Wolff and Kant, who were in my opinion genuine freethinkers, encountered different problems, especially regarding intellectual purism and the religious authorities, within the restrictive politico-religio-theological framework. In consequence, all except Leibniz were considered to be religious deviants and were accused of heretical views or defamation of the scriptures, and thus seen as either an example of proper illegal activity or exceptionable deviant activity. ${ }^{41}$

41 I would like to thank Anders Runesson, Antti Laato and several anonymous persons for useful comments offered at the Religion and Cultural Change conference, and two anonymous referees and Anni Maria Laato for advantageous feedback.
Visa Helenius is a doctoral candidate in philosophy at the University of Turku. His Ph.D. research work is on the principle of sufficient reason. He holds Lic.Soc.Sc. in Philosophy and MA in Latin philology from the Uni-

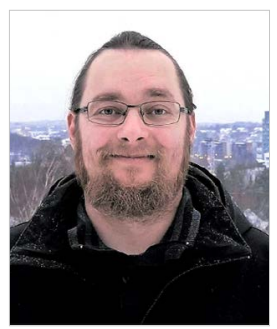
versity of Turku. His latest publication 'Lucretius and the body-environment approach' is included in SENSORIVM: The Senses in Roman Polytheism (eds. Antón Alvar Nuño, Jaime Alvar Ezquerra, and Greg Woolf, Brill 2021). He also has translated Karl Mesterton's (1715-73) dissertation De principii rationis sufficientis adplicatione ad regnum materiale et immateriale (1745) into Finnish (2019).

\section{Bibliography}

Albert, Anne. 2014. 'Rabbi and the rebels: a pamphlet on the "Herem" by Rabbi Isaac Aboab da Fonseca', Jewish Quarterly Review 104(2): 171-91, doi: <https://doi. org/10.1353/jqr.2014.0011>.

Allan, Keith. 2018. 'Religious and ideologically motivated taboos', in The Oxford Handbook of Taboo Words and Language, ed. Keith Allan (Oxford Handbooks Online), doi: <https://doi.org/10.1093/ oxfordhb/9780198808190.013.1>.

Antognazza, Maria. 2007. Leibniz on the Trinity and the Incarnation: Reason and Revelation in the Seventeenth Century, trans. Gerald Parks (New Haven, CT and London: Yale University Press), doi: <https://doi.org/10.12987/ yale/9780300100747.001.0001>.

Antognazza, Maria. 2009. Leibniz: An Intellectual Biography (Cambridge University Press), doi: <https://doi.org/10.1017/ CBO9781139012805>.

Ariew, Roger, and Daniel Garber. 1989. 'Introduction', in Gottfried Wilhelm Leibniz, Philosophical Essays, trans. Roger Ariew and Daniel Garber (Indianapolis, IN: Hackett), vii-xvi.

Beck, Lewis White. 1969. Early German Philosophy: Kant and his Predecessors (Cambridge, MA: Belknap Press of Harvard University Press).

Britannica Academic. 2021. 'Pietism', in Encyclopcedia Britannica, <academic-eb-com. 
ezproxy.utu.fi/levels/collegiate/article/Pietism/59981> (accessed 1.1.2022).

Cavanaugh, William. 2009. The Myth of Religious Violence: Secular Ideology and the Roots of Modern Conflict (New York: Oxford University Press), doi: <https://doi.org/10.1093/ acprof:oso/9780195385045.001.0001>.

Clarke, Steve. 2014. The Justification of Religious Violence (Chichester: Wiley-Blackwell).

Cliteur, Paul. 2010. 'Religion and violence' in Freedom of Religion, eds. A. van de Beek, Eduardus van der Borght, and Bernardus Vermeulen (Leiden and Boston: Brill), 235-49, doi: <https://doi.org/10.1163/ ej.9789004158078.i-269.93>.

Descartes, René. 1897-1913. Oeuvres de Descartes, 13 vols., eds. Charles Adam and Paul Tannery (Paris: Léopold Cerf).

Descartes, René. 1985a. The Philosophical Writings of Descartes, vol. 1, trans. John Cottingham, Robert Stoothoff, and Dugald Murdoch (Cambridge University Press), doi: <https://doi.org/10.1017/ CBO9780511805042>.

Descartes, René. 1985b. The Philosophical Writings of Descartes, vol. 2, trans. John Cottingham, Robert Stoothoff, and Dugald Murdoch (Cambridge University Press), doi: <https://doi.org/10.1017/ CBO9780511818998>.

Fugate, Courteny, and John Hymers. 2014. 'Introduction to the translation', in Alexander Baumgarten, Metaphysics (London, New Delhi, New York, and Sydney: Bloomsbury), $1-65$.

Gatti, Hilary 2015. Ideas of Liberty in Early Modern Europe: From Machiavelli to Milton (Princeton University Press), doi: <https:// doi.org/10.1515/9781400866304>.

Gaukroger, Stephen. 1995. Descartes: An Intellectual Biography (Oxford University Press), doi: <https://doi.org/10.1093/0198237243.0 $01.0001>$.

Goode, Erich (ed.). 2015. The Handbook of Deviance (Chichester: Wiley Blackwell), doi: $<$ https://doi.org/10.1002/9781118701386>.

Grote, Simon. 2014. 'Review. Review-essay: religion and enlightenment', Journal of the History of Ideas 75(1): 137-60.

Grote, Simon. 2017. The Emergence of Modern Aesthetic Theory (Cambridge University Press), doi: <https://doi. org/10.1017/9781316275559>.
Grote, Simon. 2018. 'Domesticating religious "fanaticism" in eighteenth-century Germany', Church History and Religious Culture 98(1): 111-38, doi: <https://doi. org/10.1163/18712428-09801023>.

Hampshire, Stuart. 1988. Spinoza (London: Penguin Books).

Hatfield, Gary. 2018. 'René Descartes', in The Stanford Encyclopedia of Philosophy (Summer 2018 Edition), ed. Edward N. Zalta, $<$ https://plato.stanford.edu/archives/ sum2018/entries/descartes/> (accessed 1.1.2022).

Hellyer, Marcus. 2008. The Scientific Revolution: The Essential Readings (Hoboken, NJ: Wiley), doi: <https://doi. org/10.1002/9780470755730>.

Hettche, Matt, and Corey Dyck. 2019. 'Christian Wolff', in The Stanford Encyclopedia of Philosophy (Winter 2019 Edition), ed. Edward Zalta, <https://plato.stanford.edu/archives/ fall2020/entries/kant/> (accessed 1.1.2022).

Hobsbawm, Eric. 1954. 'The general crisis of the European economy in the 17th century', Past \& Present 5: 33-53, doi: <https://doi. org/10.1093/past/5.1.33>.

Hsia, R. Po-Chia, and Henk Van Nierop. 2002. Calvinism and Religious Toleration in the Dutch Golden Age (Cambridge University Press), doi: <https://doi.org/10.1017/ CBO9780511496769>.

Huenemann, Charlie. 2008. Understanding Rationalism (Stocksfield: Acumen), doi: <https://doi.org/10.4324/9781315711829>.

Israel, Jonathan. 2001. Radical Enlightenment: Philosophy and the Making of Modernity, 1650-1750 (Oxford University Press), doi: $\quad<$ https://doi.org/10.1093/acprof: oso/9780198206088.001.0001>.

Kant, Immanuel. 1996. Critique of Pure Reason, trans. Werner S. Pluhar (Indianapolis, IN and Cambridge: Hackett Publishing).

Kant, Immanuel. 2009. The Critique of Practical Reason, trans. Thomas Abbott (Auckland: The Floating Press).

Leibniz, Gottfried Wilhelm. 1989. Philosophical Essays, trans. Roger Ariew and Daniel Garber (Indianapolis, IN: Hackett).

Leibniz, Gottfried Wilhelm. 1998. Theodicy: Essays on the Goodness of God, the Freedom of Man and the Origin of Evil, trans. E. Huggard (Chicago and La Salle, IL: Open Court). 
Look, Brandon. 2020. 'Gottfried Wilhelm Leibniz', in The Stanford Encyclopedia of Philosophy (Spring 2020 Edition), ed. Edward Zalta, <https://plato.stanford.edu/archives/ spr2020/entries/leibniz/> (accessed 1.1.2022).

Nadler, Steven. 1999. Spinoza: A Life (Cambridge University Press), doi: <https://doi. org/10.1017/CBO9780511815713>.

Nadler, Steven. 2004. Spinoza's Heresy: Immortality and the Jewish Mind (Oxford University Press), doi: <https://doi.org/10.1093/01 99247072.001.0001>.

Nadler, Steven. 2014. 'Introduction', in Spinoza and Medieval Jewish Philosophy, ed. Steven Nadler (Cambridge University Press), 1-12, doi: <https://doi.org/10.1017/ CBO9781139795395.001>.

Nadler, Steven. 2020. 'Baruch Spinoza', in The Stanford Encyclopedia of Philosophy (Spring 2020 Edition), ed. Edward Zalta, <https:// plato.stanford.edu/archives/sum $2020 /$ entries/spinoza/> (accessed 1.1.2022).

Nelson, Alan (ed.). 2005. A Companion to Rationalism (Malden, MA: Blackwell), doi: $<$ https://doi.org/10.1002/9780470996904>.

Pasternack, Lawrence, and Courtney Fugate. 2021. 'Kant's philosophy of religion', in The Stanford Encyclopedia of Philosophy (Summer 2021 Edition), ed. Edward Zalta, <https://plato.stanford.edu/archives/ sum2021/entries/kant-religion/> (accessed 1.1.2022).

Peters, F. E. 2007. The Voice, the Word, the Books: The Sacred Scripture of the Jews, Christians, and Muslims (Princeton University Press), doi: <https://doi. org/10.1515/9780691190471>.

Phemister, Pauline. 2006. The Rationalists (Cambridge and Malden, MA: Polity Press).

Rohlf, Michael. 2020. 'Immanuel Kant', in The Stanford Encyclopedia of Philosophy (Fall 2020 Edition), ed. Edward Zalta, <https:// plato.stanford.edu/archives/fall $2020 /$ entries/kant/> (accessed 1.1.2022).

Rüpke, Jörg. 2016. Religious Deviance in the Roman World: Superstition or Individuality?, trans. David Richardson (Cambridge University Press), doi: <https://doi. org/10.1017/CBO9781316106792>.

Russell, Bertrand. 1945. History of Western Philosophy (New York: Simon and Schuster).
Rydberg,Andreas. 2021. 'Thepersona ofthe Wolffian philosopher in early eighteenth-century Germany', Journal for Eighteenth-Century Studies 44(2): 189-204, doi: <https://doi. org/10.1111/1754-0208.12749>.

Sack, Fritz. 2007. 'Abweichung und Kriminalität', in Lehrbuch der Soziologie, ed. Hans Joas (Frankfurt and New York: Campus Verlag), 183-216.

Schoockius, Martinus. 1643. Admiranda Methodus Novae Philosophiae Renati Des Cartes (Ex officina Joannes van Waesberge).

Schwartz, Daniel. 2012. The First Modern Jew: Spinoza and the History of an Image (Princeton University Press), doi: <https://doi. org/10.1515/9781400842261>.

Scruton, Roger. 1982. Kant (Oxford University Press).

Spinoza, Baruch. 2002. Complete Works, trans. Samuel Shirley (Indianapolis, IN: Hackett Publishing).

Steenbakkers, Piet. 2009. 'The textual history of Spinoza's Ethics', in The Cambridge Companion to Spinoza's Ethics, ed. Olli Koistinen (Cambridge University Press), 26-41, doi: <https://doi.org/10.1017/ CCOL9780521853392.002>.

Stollberg-Rilinger, Barbara, and Yair Mintzker. 2018. The Holy Roman Empire: A Short History (Princeton University Press), doi: $<$ https://doi.org/10.1515/9781400890262>.

Trevor-Roper, Hugh. 1959. 'The general crisis of the 17 th century', Past \& Present 16: 31-64, doi: <https://doi.org/10.1093/ past/16.1.31>.

Trevor-Roper, Hugh. 2001. The Crisis of the Seventeenth Century: Religion, the Reformation, and Social Change (Indianapolis, IN: Liberty Fund).

Verbeek, Theo. 1991. 'Descartes and the problem of atheism: the Utrecht crisis', Nederlandsch archief voor kerkgeschiedenis 71(2): 211-23, doi: <https://doi. org/10.1163/002820391X00203>.

Verbeek, Theo. 2015a. 'Calvinism', in The Cambridge Descartes Lexicon, ed. Lawrence Nolan (Cambridge University Press), 83-4, doi: <https://doi.org/10.1017/ CBO9780511894695.038>.

Verbeek, Theo. 2015b. 'Voetius, Gysbertus (1589-1676)', in The Cambridge Descartes Lexicon, ed. Lawrence Nolan (Cambridge 
University Press), 754-56, doi: <https://doi. org/10.1017/CBO9780511894695.256>.

Voetius, Gisbertus. 1648. Selectarum disputationum theologicarum. Pars prima (Ultrajecti, apud Joannem a Waesberge).

Wolff, Christian. 1737. Theologia naturalis scientifica pertractata (Francofurti Lipsiae).

Wolff, Christian. 1751. Vernünftige Gedanken von Gott, der Welt und der Seele des Menschen, auch allen Dingen überhaupt (Halle im Magdeburgischen).

Wood, Allen. 2020. Kant and Religion (Cambridge University Press). 